\title{
Лингвистическая экспертиза современного рекламного текста из сети Интернет
}

\author{
Н. В. Гераскевич \\ Сургутский государственный педагогическийуниверситет \\ ул. 50 лет ВЛКСМ, д.10/2, 628417, г. Сургут, Россия. E-mail: nata_skazka@rambler.ru
}

\begin{abstract}
В настоящей статье рассматриваются особенности современного рекламного текста. Акцентируется внимание на когнитивной и аффективной функциях рекламы как основополагающих при создании и восприятии рекламного продукта. В представленной статье освещены правовые аспекты рекламы в современном обществе со ссылкой на нормативную правовую базу Федерального уровня. Обозначены признаки недобросовестной и неэтичной рекламы. На основании сформулированных выводов проведена лингвистическая экспертиза конкретного рекламного текста из сети Интернет. Представлен подробный лингвистический анализ рекламы в соответствии с обозначенным алгоритмом. В исследовании рассматриваются признаки рекламного текста, объект рекламирования, форма функционирования рекламного слогана. Выявлен адресат анализируемого рекламного продукта. Лингвистической экспертизе подвергнуто семантическое содержание рекламы и ее комментариев пользователями сети Интернет. Результаты лингвистической экспертизы могут быть признаны самодостаточными либо послужить основой для дальнейшего анализа указанного рекламного текста. Ключевые слова: рекламный текст, лингвистическая экспертиза, семантический анализ.
\end{abstract}

\section{Linguistic examination of modern Internet advertisement copy}

\author{
N. V. Geraskevich \\ Surgut State PedagogicalUniversity \\ 50 years of the KomsomolSt. 10/2. Surgut, 628417, Russia. \\ E-mail: nata_skazka@rambler.ru
}

\begin{abstract}
This article discusses the specifics of modern advertisement text. The author of the study focuses on the fundamental cognitive and affective functions of advertisement in the creation and perception of an advertisement product. The article illustrates the legal aspects of advertisement in modern society with reference to the federal legal framework. The characteristics of dishon est and unethical advertisement are indicated. On the basis of the drawn conclusions the linguistic expertise of an advertisement text from the Internet is carried out. A detailed linguistic analysis of advertisement in accordance with the specified algor ithm is presented. The study examines the characteristics of the advertisement text, the object of advertisement, the form of the advertisement slogan functioning. The recipient of the analyzed advertisement product is defined. The results of linguistic expertise can be considered self-sufficient or serve as a basis for further analysis of the above mentioned advertisement text.
\end{abstract} Key words: advertisement text, linguistic expertise, semantic analysis.

Современное информационное общество ориентировано на использование разнообразных цифровых ресурсов во всех сферах жизнедеятельности человека. Не является исключением и экономическая ниша. Заинтересованность производителей товаров и услуг в реализации своей продукции провоцирует рост рекламного продукта, который благодаря информационной среде можно распространять через различные цифровые носители. Большие возможности для предложений рекламодателей имеет сеть Интернет и другие социальные информационные сети.

Однако обилие рекламы не всегда прямо пропорционально её качеству. Появляются рекламные тексты, которые не соответствует этическим и нравственным нормам общества, не учитывают социокультурный или этнический аспект территории. Поэтому аудитории всё чаще приходится сталкиваться с недобросовестной рекламой, содержащей прямую агрессию или провоцирующей конфликтные ситуации в сфере общественных отношений.

Несмотря на наличие законодательной базы в отношении рекламного продукта, юристы не всегда в состоянии однозначно 
оценить правомерность либо неправомерность конкретного рекламного продукта. В подобных ситуациях необходима помощь квалифицированного лингвиста-эксперта, способного дать достаточно точную оценку текстового рекламного сообщения, выявить признаки некачественной рекламы с позиций специального лингвистического анализа текста. Нередко только совместная деятельность юристов и лингвистов позволяет дать точную характеристику рекламе в соответствии с требованиями закона.

Как полагает М.В. Баранова, правовое регулирование рекламы - неотъемлемый компонент культуры современности, отражающий менталитет народа, инструмент активизации социально-экономических и морально-психологических отношений не только в стабильных, но и в кризисных условиях. В то же время рекламное право рассматривается как самобытное средство массовой коммуникации, фактор влияния на модернизацию качества жизни, свидетельствующий о цивилизованной обусловленности прав человека [Баранова 2010:15-20]. Права и обязанности субъектов рекламной деятельности установлены различными нормативными актами, являющимися источниками разных отраслей права. В связи с этим следует различать конституционно-правовой, гражданскоправовой, административно-правовой статус субъектов рекламной деятельности ит.д.

Закон о рекламе 1995 г. создан на основе положений Международного кодекса рекламной деятельности Международной торговой палаты. К его разработке привлекались специалисты Государственного комитета по антимонопольной политике, а также зарубежные специалисты и консультанты. Российский закон о рекламе был высоко оценен Европарламентом и даже рекомендован в качестве образца для написания подобных законов в европейских странах [Федеральный закон № 108-Ф3 «О рекламе» 1995: ст.2].

Закон о рекламе 2006 г. помимо общих и особенных норм, посвященных рекламе, предлагает понятийный аппарат в сфере рекламы, общие рамки рекламных правоотношений в России, статус субъектов рекламной деятельности, в том числе профессиональных участников рекламного рынка, а также контролирующих сферу рекламы государственных органов, и их полномочия [Федеральный закон № 108-Ф3 «О рекламе» 2006: ст.5].

Закон о рекламе устанавливает дополнительные требования к рекламе отдельных видов товаров (услуг), например ценных бумаг [Федеральный закон № 39-Ф3 «О рынке ценных бумаг» 1996]. В свою очередь, «обратные» по особенностям распространения рекламной информации отсылки можно обнаружить в отраслевых законах, например, Федеральном законе от 10.07.2001 № 87-Ф3 «Об ограничении курения табака», Законе РФ от 27.12.1991 № 2124-1 «О средствах массовой информации» [Федеральный закон № 87-ФЗ «Об ограничении курения табака» 2001:ст.5; Федеральный закон № 2124-1 2001: ст.36].

В Федеральном законе от 13.03.2006 №38-Ф3 (ред. от 27.12.2018) «О рекламе» приводится дефиниция понятия рекламы.

Реклама - информация, распространенная любым способом, в любой форме и с использованием любых средств, адресованная неопределенному кругу лиц и направленная на привлечение внимания к объекту рекламирования, формирование или поддержание интереса к нему и его продвижение на рынке [Федеральный закон № 108-Ф3 «О рекламе» 2006: ст.3].

С точки зрения указанного Закона, ненадлежащая реклама - реклама, не соответствующая требованиям законодательства Российской Федерации.

С позиций непригодности рекламы для использования в социальной среде можно выделить такие характеристики, как неэтичность, недобросовестность, некорректность, недостоверность.

В правовой практике есть достаточное количество примеров недобросовестной рекламы.

Неэтичная реклама (ст. 8 Закона о рекламе РФ (ФЗ о рекламе РФ) - это реклама, содержащая текстовую, зрительную или звуковую информацию, нарушающую общепринятые нормы гуманности и морали путем употребления оскорбительных слов и выражений, а также образов в отношении расы, национальности, социальной категории, возрастной группы, пола, языка или профессии, а также религиозных, философских, политическихи иныхубеждений физическихлиц. Также неэтичной является реклама, порочащая произведения искусства, составляющие национальное или мировое культурное достояние. Запрещается порочить государственные символы, национальную валюту РФ или другой страны, а также религиозные символы [МедиаТрансУфа 2018].

По мнению О.Е. Надеждиной, реклама в современном обществе осуществляет важные экономические задачи, но часто имеет некорректную форму и недостоверное содержание [Надеждина 2010: 454].

Как утверждает вышеуказанный автор, в конечном итоге плохая реклама невыгодна всем. С одной стороны, она создаёт напряжение в обществе, с другой - приводит к снижению объёма продаж, к падению прибылей.

Несмотря на существующие требования и позиции законодательной базы о рекламе, рекламный текст всегда сложен по своему строению. Семантика речевого рекламного высказывания включает несколько типов: пропозитивный (отражение внеязыковой ситуации в тексте), иллокутивный (определение целеустановки автора в речевом акте), перлокутивный (прогнозируемый эффект или реакция адресата высказывания).

Для выяснения и доказательства некорректности рекламного текста только юридических знаний недостаточно. В этом случае дополнительно важно привлечь и лингвистические знания.

Как подчёркивает Е.С. Кара-Мурза, главная предпосылка лингвоэкспертного анализа - правовая и деонтологическая регулируемость коммуникации, ее осуществление под контролем сложной иерархии норм: не только стихийно сложившихся (хотя впоследствии и рефлексируемых) конвенций - жанрово-дискурсивных (текстовых) и речеповеденческих (тоже соответствующих речедеятельностной сфере), но и законодательных требований, государством установленных и охраняемых; а также кодексов делов ой этики, в том числе профессиональной коммуникации [Кара-Мурза 2012].

Проанализируем рекламный текст компании Reebok, получивший широкий резонанс со стороны пользователей социальных сетей: «Пересядь с иглы мужского одобрения на мужское лицо».

Российский проект стал адаптацией американской кампании Reebok, в которой приняли участие известные во всем мире актрисы, спортсменки, активистки. Только на плакатах с Gal Gadot, Nathalie Joanne Emmanuel и другими красуются менее вызывающ ие лозунги: «Поражения - это топливо для будущих побед» или, например, «Никогда не извиняйся за то, что ты сильная».

Данный рекламный слоган обладает всеми признаками рекламного текста, такими как лаконичность, конкретика, обращённость к аудитории, одна центральная идея, оригинальность, простота лексики, образность, соответствие духу компании. Объектом рекламирования является продукция компании Reebok. Цель данной рекламы - дать возможность девушкам, которые занимаются «не женскими» видами спорта - смешанными единоборствами, - проявить себя, убедить общество, что женщины также могут быть акивными, а не только заниматься домашним хозяйством. Таким образом, рекламный слоган преследовал цель отмены гендерных стереотипов. В слогане рекламируется только один объект - сильная сторона женщины в достижении успеха в спорте.

Комментарии пользователей социальных сетей показали, что реклама была воспринята как попытка дискриминировать мужчин как гендерную и социальную группу. Создатели рекламы парировали мнение общественности, утверждая, что призывают не унижать мужчин, а раскрепоститься и сломать стереотипы вместе с сильной женщиной. По словам специалиста по маркетингу, речь шла не о жестокости, а об удовольствии [Как реклама Reebok возмутила Сеть, 2019]. Однако эффект получился прямо противоположный. Это 
можно интерпретировать следующим образом: перестань быть служанкой мүжчины, стань женщиной, которая способна видеть в мужчине только соперника, слабого индивида и т.п. На наш взгляд, авторы не учли особенностей менталитета и культурныхценностей российского общества. Реклама демонстрирует негативное отношение к лицам, не пользующимся рекламируемыми товарами, поскольку апеллирует к обществу в целом, разделяя при этом его по гендерному признаку. Об этом свидетельствует тот факт, что подтекст рекламы был воспринят аудиторией как вызов мужской половине общества.

В тексте рекламы, опубликованной компанией Reebok, содержится и негативная информация окомпании, демонстрирующая ее приверженность к агрессивному феминизму через унижение мужской части общества. Выраженная таким образом информация, безусловно, повлияла на деловую репутацию компании Reebok. Это подтверждается негативными отзывами аудитории: «Нелегко живется современному мужчине, никому нельзя доверять - сперва бритва предает, теперь вот и кроссовки воткнули нож в спину»; «Вы оригинал, западную кампанию видели? Она же совершенно иначе звучит, там женственность энергичная, талантливая, самоуверенная, деятельная. Главное, она не выглядит бледной копией самой себя, не выглядит провинциально задиристой хабалкой . Именно в дизайне. Я не про конкретный месседж, это без комментариев, там все понятно» [Как реклама Reebok возмутила Ceть, 2019].

Тем не менее, несмотря на отрицательные отзывы о рекламе, по мнению авторов некоторых статей, «российскому Reebok удалось поймать хайп и, возможно, обратить на себя внимание той части женской аудитории, которая пересытилась одинаково отретушированными рекламными кампаниями спортивных брендов. Правда, глупо отрицать, что ради такого результата принесены несоразмерные жертвы» [Как реклама Reebok возмутила Сеть, 2019].

На основании анализа рекламного высказывания можно утверждать, что данный текст включает полный набор признаков неэтичной рекламы. В частности, он содержит текстовую информацию, нарушающую общепринятые нормы морали путём употребления унижающихслов, сравнений, образов в отношении пола физическихлиц (мужской части общества).

\section{Литература}

1. Баранова, М.В. Право и реклама (общетеоретический аспект): автореф. дис. ... д-ра юрид. наук. Н. Новгород, 2010.

2. Как реклама Reebok возмутила Сеть. 2019. URL: https://www.m24.ru/articles/obshchestvo/08022019/154669?utm source=CopyBuf

3. Кара-Мурза Е.С. Политическая реклама и предвыборная агитация: проблемы эффективности и законности в лингвоэкспертном освещении. 3 Межвузовская научно-практическая конференция «Эффективность массовых коммуникаций: экономический аспект», 2012. Москва, МГУ, «ГЛЭДИС». URL: expert.com/publ/satti/stati/politicheskaja reklama i predvybornaja agitacija problemy ehffektivnosti $\mathrm{i}$ zakonnosti $v$ lingvoehkspertnom 0 sveshhenii kara murza e s/4-1-0-235

4. МедиаТрансУфа, 12.02.2018. URL: https://vk.com/@mediatransufa-6-primerov-neetichnoi-reklamy-narusheniya-federalnogo-zakona

5. Надеждина О.Е. Лингвистическая экспертиза рекламных текстов. Актуальные проблемы российского права. 2010. - № 2. - С. 453458.

6. Постановление Пленума Верховного Суда РФ от 24.02.2005 № 3 «О судебной практике по делам о защите чести и достоинства

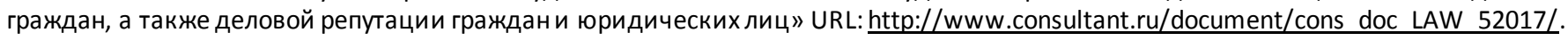

7. Радченко И.А. Учебный словарь терминов рекламы и паблик рилейшенз. Воронеж: ВФ МГЭИ, 2007.

8. Романов А. Концепции современной рекламной деятельности. Маркетинг. 2004. - № 5 (87). - С. 62- 67.

9. Федеральный закон от 18 июля 1995 г. № 108-Ф3 «О рекламе» (с изменениями от 18 июня, 14 декабря, 30 декабря 2001 г.). URL: http://base.garant.ru/10103745/.

10. Федеральный закон от $13.03 .2006 \mathrm{~N} \quad 38-\Phi 3 \quad$ (ред. http://www.consultant.ru/document/cons doc LAW 58968/.

11. Федеральный закон от 22.04.1996 № 39-Ф3 «О рынке ценных бумаг». URL: http://base.garant.ru/10106464/.

12. Федеральный закон от 10 июля 2001 г. N 87-Ф3 «Об ограничении курения табака» URL: http://base.garant.ru/183519/.

13. Федеральный закон от 27.12.1991 № 2124-1 «О средствахмассовой информации». URL: http://base.garant.ru/10164247/.

14. Что такое рекламный текст? Особенности, структура, виды рекламных текстов. URL: http://www.kadrof.ru/mk/14710

15. Экономика. Толковый словарь. Под ред. Дж. Блэк. М., 2000.

\section{References}

1. Baranova, M. V. (2010). Law and advertisement (General theoretical aspect). Thesis of Doctoral Dissertation. N. Novgorod (in Russian).

2. Economy. Explanatory dictionary. (2000). Black J. (Ed.). Moscow. (in Russian).

3. Federal Law No. 108-FZ. (1995). On advertisement. Available from: http://base.garant.ru/10103745/ (in Russian).

4. Federal Law No 38-Ф3. (2006). On advertisement. Available from: http://www.consultant.ru/document/cons doc LAW 58968/ (in Russian).

5. Federal Law No. 39-FZ. (1996). On the securities market. Available from: http://base.garant.ru/10106464/ (in Russian).

6. Federal Law No 87-FZ. (2001). About restriction of Smoking of tobacco. Avalable from: http://base.garant.ru/183519. (in Russian).

7. Federal Law No. 2124-1. (1991). On mass media. Available from: http://base.garant.ru/10164247/(in Russian).

8. How Reebok advertisement angered the Network. (2019). Available from:

https://www.m24.ru/articles/obshchestvo/08022019/154669?utm source=CopyBuf (in Russian).

9. Kara-Murza, E. S. (2012). Political advertisement and election campaigning: problems of efficiency and legality in linguo-expert coverage. Proceed. 3 Interuniversity scientific-practical conference "The effectiveness of mass communications: economic aspect" Moscow. Moscow State University. Gladys Press. Available from: http://siberiaexpert.com/publ/satti/stati/politicheskaja reklama i predvybornaja agitacija problemy ehffektivnosti i zakonnosti $v$ lingvoehkspertnom o sveshhenii kara murza e s/4-1-0-235 (in Russian).

10. Media TRANS Ufa. (2018). Available from: https://vk.com/@mediatransufa-6-primerov-neetichnoi-reklamy-narusheniya-federalnogozakona/ (in Russian).

11. Nadezhdina, O.E. (2010). Linguistic expertise of advertisement texts. Actual Problems of Russian Law, 2, 453-458. (in Russian).

12. Radchenko, I.A. (2007). Educational dictionary of advertisement terms and public relations. Voronezh: WF MGEI (in Russian).

13. Resolution of the Plenum of the Supreme Court. (2005). On judicial practice in cases of protection of honor and dignity of citizens, as

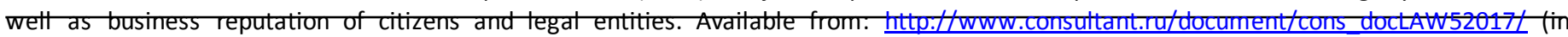


Russian).

14. Romanov, A. (2004). Concepts of modern advertising. Marketing, 5(87), 62-67 (in Russian).

15. What is an advertisement text? Features, structure, types of advertisement texts. (2018). Available from: http://www.kadrof.ru/mk/14710 (in Russian).

\section{Citation:}

Гераскевич Н.В. Лингвистическая экспертиза современного рекламного текста из сети Интернет. // Юрислингвистика. - 2019. - 13. - С. $14-17$. Geraskevich, N.V. (2019). Linguistic examination of modern Internet advertisement copy. Legal Linguistics, 13, 14-17.

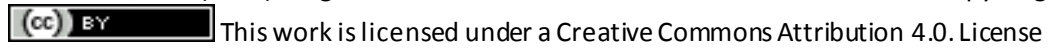

